\title{
Epitope Analysis of Anti-SARS-CoV-2 Neutralizing Antibodies*
}

\author{
Jun-biao XUE, Sheng-ce TAO \\ Shanghai Center for Systems Biomedicine, Key Laboratory of Systems Biomedicine (Ministry of Education), Shanghai Jiao \\ Tong University, Shanghai 200240, China
}

(C) Huazhong University of Science and Technology 2021

\begin{abstract}
[Abstract] Coronavirus disease 2019 is threatening thousands of millions of people around the world. In the absence of specific and highly effective medicines, the treatment of infected persons is still very challenging. As therapeutics, neutralizing antibodies (NAbs) have great potential. Many NAbs have been reported, and most target various regions on the receptor-binding domain of the spike (S) protein, or the N-terminal domain. Several NAbs and NAb cocktails have been authorized for emergency use, and more are in clinical trials or are under development. In this review, considering the angle of binding epitopes on the $\mathrm{S}$ protein, we summarize the functions and the underlying mechanisms of a set of well-recognized NAbs and provide guidance for vaccine design and the combinatorial use of these antibodies. In addition, we review the NAbs and NAb cocktails that have been approved for emergency use and discuss the effectiveness of these NAbs for combating severe acute respiratory syndrome coronavirus 2 mutants.

Key words: coronavirus disease 2019; severe acute respiratory syndrome coronavirus 2; neutralizing antibody; epitope; therapeutics; vaccine
\end{abstract}

The coronavirus disease 2019 (COVID-19) pandemic is caused by severe acute respiratory syndrome coronavirus 2 (SARS-CoV-2). There were 170813421 reported cases and 3557598 deaths in 219 regions and countries as of June 3, 2021 (http://2019ncov.chinacdc.cn/2019-nCoV/global. html). Several vaccines have already been approved for emergency use, and the injection of the vaccine provides a good protective barrier. However, globally, vaccination is still far from sufficient for building herd immunity, and the number of infections in many countries and regions is still increasing rapidly. To date, apart from remdesivir and dexamethasone, which have shown some clinical efficacy ${ }^{[1,2]}$, there are no specific and highly efficient medicines. Convalescent plasma contains neutralizing antibodies (NAbs) against the SARS-CoV-2 spike (S) protein, but controversial therapeutic effects have been reported ${ }^{[3-5]}$. NAbs are the major effective agents of convalescent plasma. Many monoclonal NAbs have been successfully isolated and cloned from recovered patients, and good therapeutic effects have been observed for some of these NAbs. The U.S. Federal Drug Administration

Jun-biao XUE, E-mail: junbiaoxue@sjtu.edu.cn \#Corresponding author, E-mail: taosc@sjtu.edu.cn ${ }^{*}$ This work was supported by the National Natural Science Foundation of China (Nos. 31970130, 31600672, 31670831, and 31370813). has approved emergency use of several of these NAbs, for example, LY3819253 (LY-CoV555), REGNCOV2 (REGN10933 and REGN10987), and CT-P59 for treating COVID-19. COVID-19 NAbs have been extensively reviewed ${ }^{[6-8]}$. Herein, considering the angle of binding epitopes on the $\mathrm{S}$ protein, we summarize the latest developments, including the structures, functions, and underlying mechanisms of a set of well-recognized NAbs and the effectiveness of several approved NAbs for use in treating SARS-CoV-2 mutants, such as B.1.1.7, B.1.351, and P.1.

\section{SARS-CoV-2 SPIKE PROTEIN AND ITS CELL SURFACE RECEPTOR}

SARS-CoV-2 invades host cells through the $\mathrm{S}$ transmembrane glycoprotein on the virus surface. The $\mathrm{S}$ protein is a homotrimer (fig. 1A), and each monomer contains two functional subunits, $\mathrm{S} 1$ and $\mathrm{S} 2$. S1 contains a receptor-binding domain (RBD), which binds to a receptor, human angiotensin-converting enzyme 2 (ACE2), and the binding interface closest to the RBD is the receptor-binding motif (RBM) (fig. $1 \mathrm{C}$ and 1D). The N-terminal domain (NTD) of S1 may recognize glycosyl groups during initial binding and may play an important role in the transition of the $\mathrm{S}$ protein from prefusion to postfusion in some coronaviruses $^{[6,9]}$. The S2 subunit contains a fusion peptide (FP), heptad repeat 1 (HR1), and heptad 
repeat 2 (HR2) (fig. 1A). There is a specific furin protease cleavage site near the fusion peptide, referred to as S2'. To interact with the host cell receptor, the RBD undergoes a hinge-like conformational change, forming two conformational states: a "down/close" state in which the receptor-binding region is hidden and an "up/open" state in which the receptor binding region is exposed (fig. $1 \mathrm{~A}$ and $1 \mathrm{~B}$ ) ${ }^{[10,11]}$. When the RBD is in the "up" state, it can combine with ACE2 and destabilize the prefusion-inducing trimer, resulting in shedding of the S1 subunit and transitioning of the S2

A

B

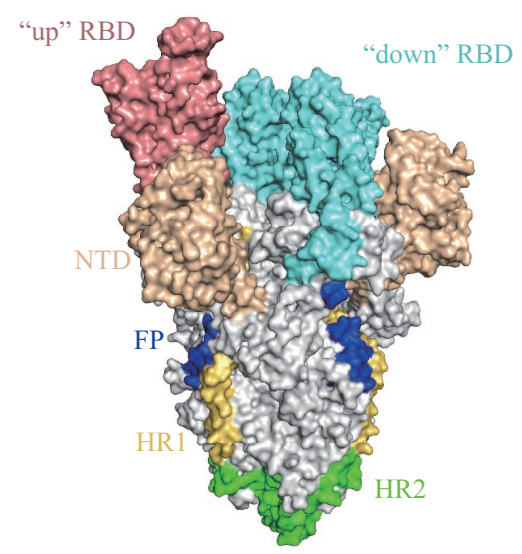

subunit into a stable postfusion conformation ${ }^{[12]}$. In this process, the $\mathrm{S}^{\prime}$ site can be cleaved by transmembrane protease serine 2 (TMPRSS2) or TMPRSS4 ${ }^{[13]}$, two host cell serine proteases, or furin ${ }^{[14,15]}$. After cleavage, the two subunits remain noncovalently bound ${ }^{[15-17]}$. The exposed fusion peptide can insert into the cell membrane of the host, where HR1 and HR2 are refolded and form a fused conformation linking the virus and the host cell membrane together, thereby driving the membrane fusion of the virus with the target cell. The viral genes are then released into the host cell ${ }^{[14,18,19]}$.

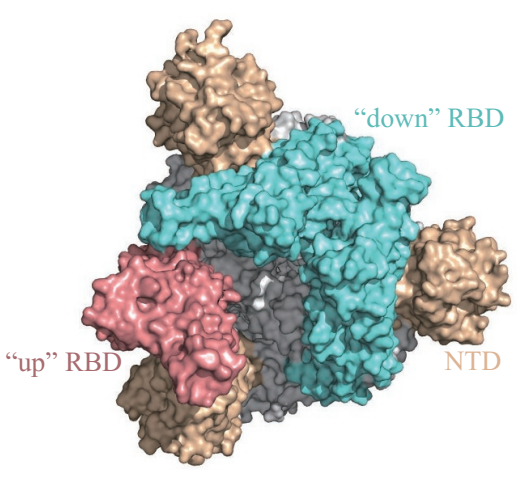

C

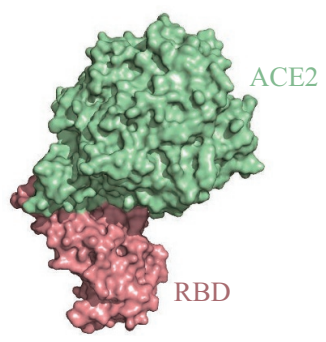

D

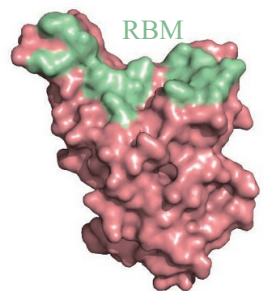

Fig. 1 Structures of the spike (S) protein, receptor-binding domain (RBD), and cell surface receptor human angiotensin-converting enzyme 2 (ACE2)

A: structural diagram of SARS-CoV-2 S trimers (PDB: 7KNE) with one "up" state RBD. The molecular surface of the trimeric protein of SARS-CoV-2 is shown with the "up" RBD, "down" RBD, NTD, FP, HR1, and HR2 colored in salmon red, cyan, light orange, blue, yellow orange, and green, respectively. B: top view of (A). C: surface representation of the RBD with ACE2 (PDB: 7KMB) colored in salmon red and pale green. D: surface representation of the RBD (PDB:7KMB) and the receptorbinding motif (RBM) in pale green.

\section{ANTI-SARS-CoV-2 NAbs: EPITOPES, FUNCTIONS, AND MECHANISMS}

Because of the critical role of the $\mathrm{S}$ protein in binding to the host receptor and mediating membrane fusion, it is the main target of NAbs ${ }^{[10]}$. The structures of many NAbs in complexes with the $\mathrm{S}$ protein or the RBD have been determined. These data reveal that different regions of the $\mathrm{S}$ protein or the RBD can induce different antibodies to trigger different neutralization mechanisms. The NAbs against the $\mathrm{S}$ protein are summarized in table 1 . These NAbs can be categorized into five types (type I to type V) according to the $\mathrm{S}$ protein epitopes that they target. Interestingly, NAbs of the same type have similar epitopes, and their neutralization mechanisms are generally similar.

\subsection{Type I NAbs}

Type I NAbs bind only to one RBD in the "up" state (table 1, fig. 2A). They mainly bind to the binding interface between the RBD and ACE2, thus competing with ACE2 for binding the RBD and inhibiting the cell entry of SARS-CoV-2. All type I NAbs have a good neutralizing effect. For example, the half maximal inhibitory concentration $\left(\mathrm{IC}_{50}\right)$ of $\mathrm{C} 105$ against SARSCoV-2 pseudovirus was found to be $26.1 \mathrm{ng} / \mathrm{mL}$ in vitro ${ }^{[20]}$. In addition, CV07-250 has an $\mathrm{IC}_{50}$ value of 3.5 $\mathrm{ng} / \mathrm{mL}$ against authentic virus ${ }^{[21]}$. Moreover, CB6 has a $50 \%$ neutralization dose (ND50) value of $0.036 \pm 0.007$ $\mu \mathrm{g} / \mathrm{mL}$ on live SARS-CoV-2 infection in Vero E6 cells, and a single dose of $\mathrm{CB} 6$, which has two leucine-toalanine substitutions at residues 234 and $235(50 \mathrm{mg} /$ $\mathrm{kg}$ body weight) before challenge with SARS-CoV-2, can protect macaques from infection ${ }^{[22]}$. For B38, a single dose $(25 \mathrm{mg} / \mathrm{kg})$ can protect ACE2-transgenic mice from SARS-CoV-2 infection, and its $\mathrm{IC}_{50}$ value is $177 \mathrm{ng} / \mathrm{mL}$ against authentic virus ${ }^{[23]}$.

\subsection{Type II NAbs}

For binding, type II NAbs require at least two "up" RBDs; they may not bind to one "up" RBD due to steric hindrance (table 1, fig. 2B). These NAbs require more-specific binding conditions, which may explain why there are fewer antibodies of this type. These NAbs bind to the hinge region at the bottom of the $\mathrm{RBD}$, and this region is relatively conserved between 
A

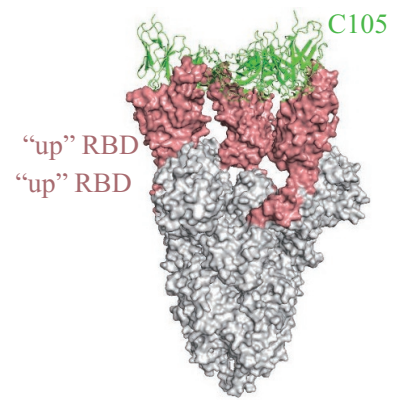

B

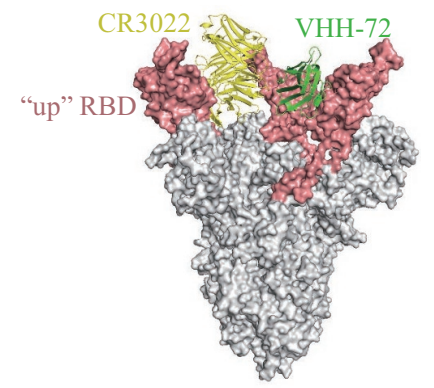

$\mathrm{C}$

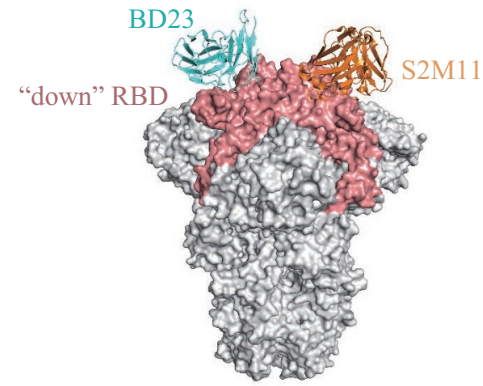

$\mathrm{D}$

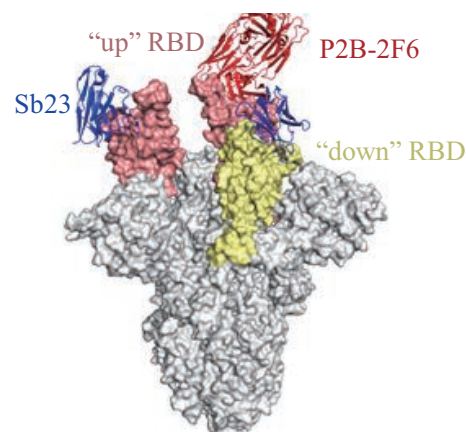

E

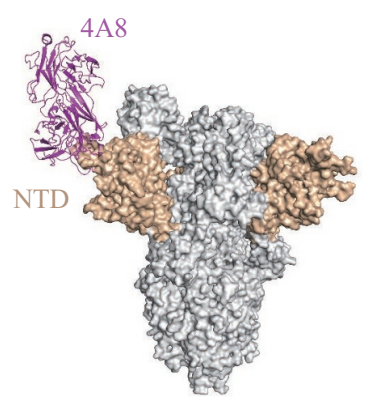

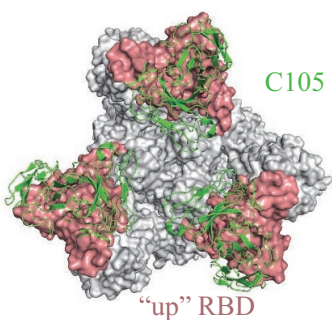
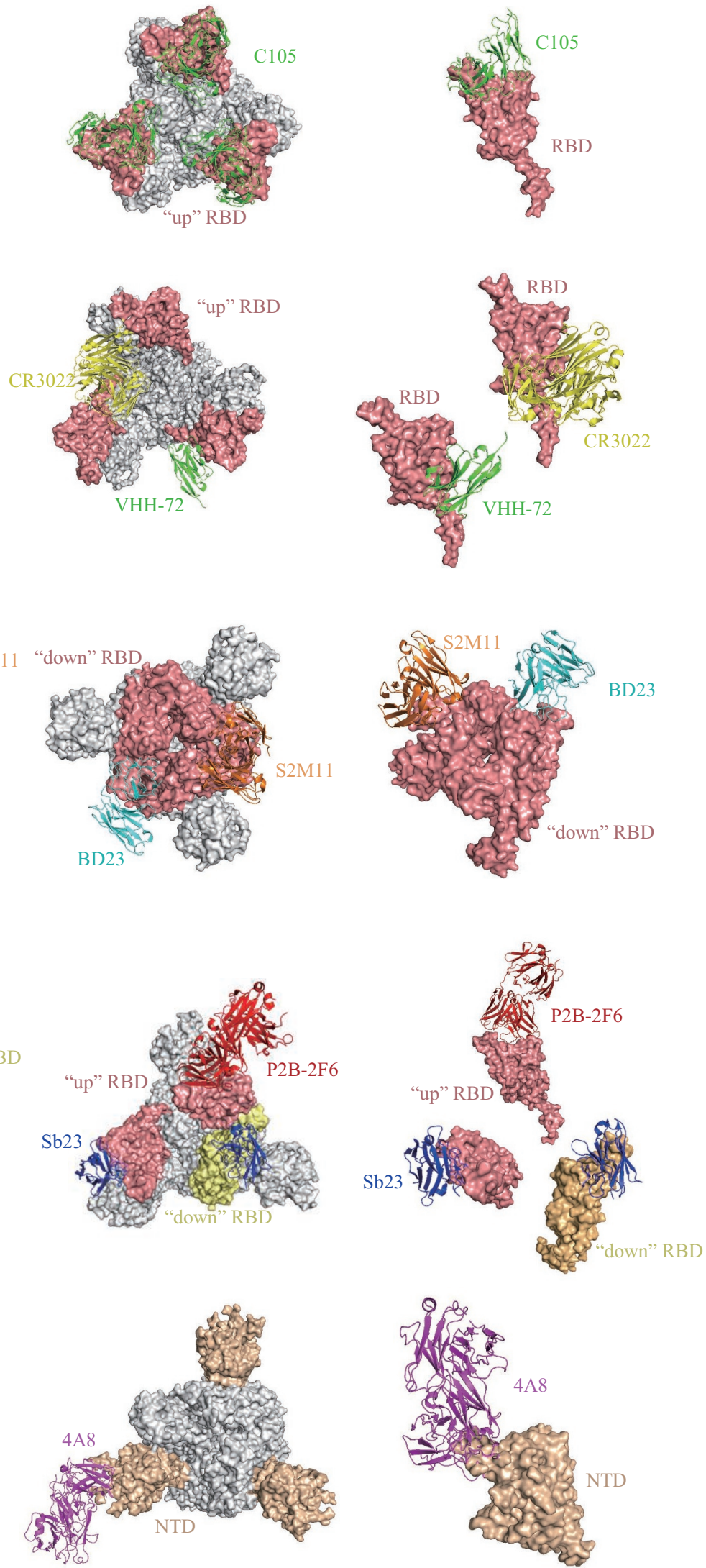

Fig. 2 SARS-CoV-2 neutralizing antibodies (NAbs) are classified into five groups with different binding mechanisms A: Type I NAbs (e. g., C105, PDB: 6XCN) only bind to the RBD in the "up" state. B: When at least two RBDs are in the "up" state, type II NAbs (e. g., CR3022, PDB: 6YOR and VHH-72, PDB: 6WAQ) bind to the S trimer. C: Type III NAbs (e. g., BD23, PDB: 7BYR and S2M11, PDB: 7K43) only bind to the RBD in the "down" state. D: Type IV NAbs (e. g., Sb23, PDB: 7A29 and P2B-2F6, PDB: 7BWJ) can bind to the RBD both in the "up" and "down" states. E: Type V NAbs (e. g., 4A8, PDB:7C2L) can bind to the NTD. 
Table 1 SARS-CoV-2 neutralizing antibodies

\begin{tabular}{|c|c|c|c|c|c|c|c|}
\hline Type & $\begin{array}{l}\text { Antibody } \\
\text { name }\end{array}$ & Origin & $\begin{array}{l}\text { PDB ID or } \\
\text { EMDB ID }\end{array}$ & $\begin{array}{c}\mathrm{IC}_{50}^{\# / \mathrm{IC}_{50}}{ }^{\# \#} \\
(\mathrm{ng} / \mathrm{mL})\end{array}$ & $\begin{array}{l}\text { Neutralizing } \\
\text { mechanism }\end{array}$ & $\begin{array}{l}\text { Heavy } \\
\text { V gene }\end{array}$ & Ref. \\
\hline \multirow{15}{*}{ Type I } & C105 & $\begin{array}{c}\text { COVID-19 } \\
\text {-convalescent patients }\end{array}$ & 6XCN, 6XCM & $26.1 /-$ & $\begin{array}{l}\text { Block the hACE2- } \\
\text { RBD interaction }\end{array}$ & IGHV3-53 & [20] \\
\hline & C102 & $\begin{array}{c}\text { COVID-19 } \\
\text {-convalescent patients }\end{array}$ & $7 \mathrm{~K} 8 \mathrm{M}$ & $34 /-$ & $\begin{array}{l}\text { Block the hACE2- } \\
\text { RBD interaction }\end{array}$ & IGHV3-53 & [20] \\
\hline & $\mathrm{CB} 6^{\triangle}$ & $\begin{array}{c}\text { COVID-19 } \\
\text {-convalescent patients }\end{array}$ & $7 \mathrm{C} 01$ & $23 / 36$ & $\begin{array}{l}\text { Block the hACE2- } \\
\text { RBD interaction }\end{array}$ & IGHV3-66 & [51] \\
\hline & B38 & $\begin{array}{c}\text { COVID-19 } \\
\text {-convalescent patients }\end{array}$ & $7 \mathrm{BZ5}$ & $-/ 177$ & $\begin{array}{l}\text { Block the hACE2- } \\
\text { RBD interaction }\end{array}$ & IGHV3-53 & [23] \\
\hline & CV30 & $\begin{array}{l}\text { Infected COVID-19 } \\
\text { patients }\end{array}$ & $6 \mathrm{XE} 1$ & $30 / 118$ & $\begin{array}{l}\text { Block the hACE2- } \\
\text { RBD interaction }\end{array}$ & IGHV3-53 & [52] \\
\hline & CC12.3 & $\begin{array}{c}\text { COVID-19 } \\
\text {-convalescent patients }\end{array}$ & $6 \mathrm{XC7}$ & $18 / 26$ & $\begin{array}{l}\text { Block the hACE2- } \\
\text { RBD interaction }\end{array}$ & IGHV3-53 & [53] \\
\hline & CC12.1 & $\begin{array}{c}\text { COVID-19 } \\
\text {-convalescent patients }\end{array}$ & $6 \mathrm{XC} 3$ & $19 / 120$ & $\begin{array}{l}\text { Block the hACE2- } \\
\text { RBD interaction }\end{array}$ & IGHV3-53 & [53] \\
\hline & BD-629 & $\begin{array}{c}\text { COVID-19 } \\
\text {-convalescent patients }\end{array}$ & $7 \mathrm{CH} 5$ & $6 /-$ & $\begin{array}{l}\text { Block the hACE2- } \\
\text { RBD interaction }\end{array}$ & IGHV3-53 & [54] \\
\hline & CA1 & $\begin{array}{c}\text { COVID-19 } \\
\text {-convalescent patients }\end{array}$ & - & $\begin{array}{l}\mathrm{ND}_{50} \text { for authentic } \\
\text { virus }=0.38 \mu \mathrm{g} / \mathrm{mL}\end{array}$ & $\begin{array}{l}\text { Block the hACE2- } \\
\text { RBD interaction }\end{array}$ & - & [22] \\
\hline & COVA2-39 & $\begin{array}{c}\text { COVID-19 } \\
\text {-convalescent patients }\end{array}$ & 7JMP & $36 / 54$ & $\begin{array}{l}\text { Block the hACE2- } \\
\text { RBD interaction }\end{array}$ & IGHV3-53 & [55] \\
\hline & COVA2-04 & $\begin{array}{c}\text { COVID-19 } \\
\text {-convalescent patients }\end{array}$ & 7JMO & $220 / 2500$ & $\begin{array}{l}\text { Block the hACE2- } \\
\text { RBD interaction }\end{array}$ & IGHV3-53 & [55] \\
\hline & $\mathrm{REGN} 10933^{\triangle}$ & $\begin{array}{l}\text { Humanized mice } \\
\text { and COVID-19 } \\
\text {-convalescent patients }\end{array}$ & $6 \mathrm{XDG}$ & $6.4 / 5.6$ & $\begin{array}{l}\text { Block the hACE2- } \\
\text { RBD interaction, } \\
\text { ADCC \& ADCP }\end{array}$ & IGHV3-11 & [56] \\
\hline & S2E12 & $\begin{array}{c}\text { COVID-19 } \\
\text {-convalescent patients }\end{array}$ & $7 \mathrm{~K} 45$ & $2.3 / 4.2$ & $\begin{array}{l}\text { Block the hACE2- } \\
\text { RBD interaction }\end{array}$ & IGHV1-58 & [30] \\
\hline & CV07-250 & $\begin{array}{c}\text { Infected COVID-19 } \\
\text { patients }\end{array}$ & 6XKQ & $-/ 3.5$ & $\begin{array}{l}\text { Block the hACE2- } \\
\text { RBD interaction }\end{array}$ & IGHV1-18 & [21] \\
\hline & $\mathrm{S} 2 \mathrm{H} 14$ & $\begin{array}{c}\text { Infected COVID-19 } \\
\text { patients }\end{array}$ & $7 \mathrm{JX} 3$ & $900 /-$ & $\begin{array}{l}\text { Block the hACE2- } \\
\text { RBD interaction }\end{array}$ & IGHV3-15 & [57] \\
\hline \multirow{6}{*}{ Type II } & CR3022* & Patients with SARS-CoV & 6YOR,6W41 & $-/ 114^{\$}$ & $\begin{array}{l}\text { Trap the RBD in the } \\
\text { up conformation }\end{array}$ & IGHV5-51 & [58] \\
\hline & EY6A* $^{*}$ & $\begin{array}{l}\text { COVID-19-convalescent } \\
\text { patients }\end{array}$ & $\begin{array}{c}\text { 6ZDH,6ZER, } \\
\text { 6ZCZ }\end{array}$ & $-/ 70-20000$ & $\begin{array}{l}\text { Trap the RBD in the } \\
\text { up conformation }\end{array}$ & IGHV3-30-3 & [26] \\
\hline & VHH-72* & $\begin{array}{l}\text { llama immunized with } \\
\text { SARS-CoV S protein and } \\
\text { MERS-CoV S protein }\end{array}$ & 6WAQ & $200 /-$ & $\begin{array}{l}\text { Trap the RBD in the } \\
\text { up conformation }\end{array}$ & IGHV3-3 & [27] \\
\hline & $\mathrm{H} 014^{*} \triangle$ & $\begin{array}{l}\text { Antibody library from } \\
\text { recombinant SARS-CoV } \\
\text { RBD immunized mice }\end{array}$ & 7CAH & $450 / 5700$ & $\begin{array}{l}\text { Compete with } \\
\text { recombinant ACE2 } \\
\text { for binding to the } \\
\text { RBD }\end{array}$ & IGHV1-69-2 & [28] \\
\hline & $\mathrm{S} 304^{*}$ & Patients with SARS-CoV & 7JW0 & $>5000 /-$ & $\begin{array}{l}\text { Trap the RBD in the } \\
\text { up conformation }\end{array}$ & IGHV3-13 & [57] \\
\hline & $\mathrm{S} 2 \mathrm{~A} 4$ & $\begin{array}{c}\text { COVID-19 } \\
\text {-convalescent patients }\end{array}$ & 7JVA & $3500 /-$ & $\begin{array}{c}\text { S2A4 and ACE2 } \\
\text { compete for binding } \\
\text { to the SARS-CoV } \\
-2 \text { RBD }\end{array}$ & IGHV3-7 & [57] \\
\hline \multirow{4}{*}{ Type III } & Fab 2-4 & $\begin{array}{l}\text { Infected COVID-19 } \\
\text { patients }\end{array}$ & $6 \mathrm{XEY}$ & $394 / 57$ & $\begin{array}{l}\text { Lock the RBD in the } \\
\text { down conformation }\end{array}$ & IGHV1-18 & [31] \\
\hline & $\mathrm{BD} 23$ & $\begin{array}{c}\text { COVID-19 } \\
\text {-convalescent patients }\end{array}$ & 7BYR & $4800 / 8500$ & $\begin{array}{l}\text { Block the hACE2- } \\
\text { RBD interaction }\end{array}$ & unknown & [29] \\
\hline & S2M11 & $\begin{array}{l}\text { Infected COVID-19 } \\
\text { patients }\end{array}$ & $7 \mathrm{~K} 43$ & $2.1 / 1.2$ & $\begin{array}{l}\text { Block the hACE2- } \\
\text { RBD interaction, } \\
\text { lock the RBD in the } \\
\text { down conformation }\end{array}$ & IGHV1-2 & [30] \\
\hline & Fab 2-43 & $\begin{array}{c}\text { Infected COVID-19 } \\
\text { patients }\end{array}$ & 22,275 & $71 / 3$ & $\begin{array}{l}\text { Lock the RBD in the } \\
\text { down conformation }\end{array}$ & IGLV2-14 & [31] \\
\hline
\end{tabular}




\begin{tabular}{|c|c|c|c|c|c|c|c|}
\hline Type & $\begin{array}{l}\text { Antibody } \\
\text { name }\end{array}$ & Origin & $\begin{array}{l}\text { PDB ID or } \\
\text { EMDB ID }\end{array}$ & $\begin{array}{c}\mathrm{IC}_{50}{ }^{\# / \mathrm{IC}_{50}}{ }^{\#} \\
(\mathrm{ng} / \mathrm{mL})\end{array}$ & $\begin{array}{l}\text { Neutralizing } \\
\text { mechanism }\end{array}$ & $\begin{array}{l}\text { Heavy } \\
\text { V gene }\end{array}$ & Ref. \\
\hline & $\mathrm{S} 309^{*} \triangle$ & Patients with SARS-CoV & 6WPT,6WPS & $190 / 79$ & $\mathrm{ADCC} \& \mathrm{ADCP}$ & IGHV1-18 & [59] \\
\hline & H11-H4 & $\begin{array}{c}\text { Naive llama VHH library } \\
\text { by in vitro phage display } \\
\text { technology }\end{array}$ & $6 \mathrm{ZHD}$ & $300 /-$ & $\begin{array}{l}\text { Block hACE2-RBD } \\
\text { interaction }\end{array}$ & IGHV3-3 & [60] \\
\hline & H11-D4 & $\begin{array}{c}\text { Naive llama VHH library } \\
\text { by in vitro phage display } \\
\text { technology }\end{array}$ & $6 \mathrm{Z} 43,6 \mathrm{Z} 2 \mathrm{M}$ & $900 /-$ & $\begin{array}{l}\text { Block hACE2-RBD } \\
\text { interaction }\end{array}$ & IGHV3-3 & [60] \\
\hline & P2B-2F6 & $\begin{array}{l}\text { COVID-19-convalescent } \\
\text { patients }\end{array}$ & 7BWJ & $50 / 410$ & $\begin{array}{l}\text { Block hACE2-RBD } \\
\text { interaction and }\end{array}$ & IGHV4-38-2 & [32] \\
\hline & REGN10987^ & $\begin{array}{l}\text { Humanized mice and } \\
\text { COVID-19- } \\
\text { convalescent patients }\end{array}$ & $6 \mathrm{XDG}$ & $6.1 / 6.3$ & $\begin{array}{l}\text { Compete } \\
\text { with ACE2 for } \\
\text { recognition of the } \\
\text { SARS-CoV-2 RBD }\end{array}$ & IGHV3-30 & [56] \\
\hline & BD-368-2 $2^{\triangle}$ & $\begin{array}{c}\text { COVID-19 } \\
\text {-convalescent patients }\end{array}$ & $7 \mathrm{CHF}$ & $1.2 / 15$ & $\begin{array}{l}\text { Block hACE2-RBD } \\
\text { interaction }\end{array}$ & IGHV3-23 & [54] \\
\hline & Ty1 & $\begin{array}{c}\text { Alpaca immunized with } \\
\text { SARS-CoV-2 S1-Fc and } \\
\text { RBD. }\end{array}$ & $6 \mathrm{ZXN}$ & $770 /-$ & $\mathrm{ADCC} \& \mathrm{ADCP}$ & IGHV3-3 & [61] \\
\hline \multirow[t]{8}{*}{ Type IV } & $\mathrm{S} 2 \mathrm{H} 13$ & $\begin{array}{l}\text { Infected COVID-19 } \\
\text { patients }\end{array}$ & $7 \mathrm{JV} 2$ & $500 /-$ & $\begin{array}{l}\text { Block the hACE2- } \\
\text { RBD interaction, } \\
\text { cause drastic } \\
\text { conformational } \\
\text { changes of the } \mathrm{S} \\
\text { trimer }\end{array}$ & IGHV3-7 & [57] \\
\hline & $\mathrm{Sb} 23$ & Synthetic nanobody library & 7A29 & $600 /-$ & $\begin{array}{l}\text { Block the hACE2- } \\
\text { RBD interaction }\end{array}$ & IGHV3-3 & [33] \\
\hline & C144 & $\begin{array}{c}\text { COVID-19 } \\
\text {-convalescent patients }\end{array}$ & $7 \mathrm{~K} 90$ & $6.9 / 2.6$ & $\begin{array}{l}\text { Compete with ACE2 } \\
\text { for recognition of } \\
\text { the SARS-CoV-2 } \\
\text { RBD }\end{array}$ & IGHV3-53 & [62] \\
\hline & $\mathrm{C} 002$ & $\begin{array}{c}\text { COVID-19 } \\
\text {-convalescent patients }\end{array}$ & $7 \mathrm{~K} 8 \mathrm{~T}$ & $8.9 /-$ & $\begin{array}{l}\text { Compete with ACE2 } \\
\text { for recognition of } \\
\text { the SARS-CoV-2 } \\
\text { RBD }\end{array}$ & IGVH3-30 & [62] \\
\hline & $\mathrm{C} 119$ & $\begin{array}{c}\text { COVID-19 } \\
\text {-convalescent patients }\end{array}$ & $7 \mathrm{~K} 8 \mathrm{~W}$ & $9.1 /-$ & $\begin{array}{l}\text { Lock the RBD in the } \\
\text { down conformation }\end{array}$ & IGHV4-34 & [62] \\
\hline & $\mathrm{C} 121$ & $\begin{array}{c}\text { COVID-19 } \\
\text {-convalescent patients }\end{array}$ & $7 \mathrm{~K} 8 \mathrm{X}$ & $6.7 / 1.6$ & $\begin{array}{l}\text { Lock the RBD in the } \\
\text { down conformation }\end{array}$ & IGHV1-2 & [63] \\
\hline & C104 & $\begin{array}{c}\text { COVID-19 } \\
\text {-convalescent patients }\end{array}$ & $7 \mathrm{~K} 8 \mathrm{U}$ & $23.3 /-$ & $\begin{array}{l}\text { Lock the RBD in the } \\
\text { down conformation }\end{array}$ & IGHV1-46 & [62] \\
\hline & CV07-270 & $\begin{array}{c}\text { Infected COVID-19 } \\
\text { patients }\end{array}$ & $6 \mathrm{XKP}$ & $-/ 82.3$ & $\begin{array}{l}\text { Lock the RBD in the } \\
\text { down conformation }\end{array}$ & IGHV3-11 & [21] \\
\hline \multirow{7}{*}{ Type V } & $4 \mathrm{~A} 8$ & $\begin{array}{l}\text { COVID-19-convalescent } \\
\text { patients }\end{array}$ & $7 \mathrm{C} 2 \mathrm{~L}$ & $49000 / 390$ & $\begin{array}{l}\text { May restrain the } \\
\text { conformational } \\
\text { changes of the } S \\
\text { protein }\end{array}$ & IGHV1-24 & [35] \\
\hline & FC05 & $\begin{array}{l}\text { COVID-19-convalescent } \\
\text { patients }\end{array}$ & 7CWU & -/about $0.8 \mathrm{nM}$ & - & - & [37] \\
\hline & FC06 & $\begin{array}{l}\text { COVID-19-convalescent } \\
\text { patients }\end{array}$ & - & -/about $3 \mathrm{nM}$ & - & - & [37] \\
\hline & $\mathrm{FC} 07^{*}$ & $\begin{array}{l}\text { COVID-19-convalescent } \\
\text { patients }\end{array}$ & - & $-/>700 \mathrm{nM}$ & - & - & [37] \\
\hline & $2-17$ & $\begin{array}{c}\text { Infected COVID-19 } \\
\text { patients }\end{array}$ & - & $168 / 7$ & - & - & [31] \\
\hline & $5-24$ & $\begin{array}{l}\text { Infected COVID-19 } \\
\text { patients }\end{array}$ & - & $13 / 8$ & - & - & [31] \\
\hline & $4-8$ & $\begin{array}{c}\text { Infected COVID-19 } \\
\text { patients }\end{array}$ & 22,158 & $32 / 9$ & - & IGHV1-69 & [31] \\
\hline
\end{tabular}




\begin{tabular}{|c|c|c|c|c|c|c|c|}
\hline Type & $\begin{array}{l}\text { Antibody } \\
\text { name }\end{array}$ & Origin & $\begin{array}{l}\text { PDB ID or } \\
\text { EMDB ID }\end{array}$ & 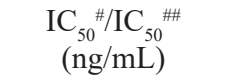 & $\begin{array}{l}\text { Neutralizing } \\
\text { mechanism }\end{array}$ & $\begin{array}{l}\text { Heavy } \\
\text { V gene }\end{array}$ & Ref \\
\hline & FC118* & $\begin{array}{l}\text { COVID-19-convalescent } \\
\text { patients }\end{array}$ & & -/about $70 \mathrm{nM}$ & - & - & [37] \\
\hline & $\mathrm{FC} 120^{*}$ & $\begin{array}{l}\text { COVID-19-convalescent } \\
\text { patients }\end{array}$ & & -/about $110 \mathrm{nM}$ & - & - & [37] \\
\hline & FC122* & $\begin{array}{l}\text { COVID-19-convalescent } \\
\text { patients }\end{array}$ & & -/about $30 \mathrm{nM}$ & - & - & [37] \\
\hline & FC124* & $\begin{array}{l}\text { COVID-19-convalescent } \\
\text { patients }\end{array}$ & & -/about $50 \mathrm{nM}$ & - & - & [37] \\
\hline
\end{tabular}

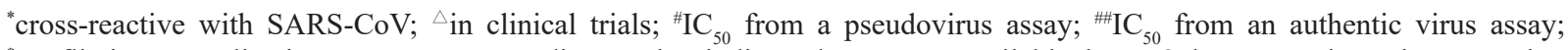
$\$$ conflicting neutralization reports across studies. Dashes indicate data are not available. hACE2, human angiotensin-converting enzyme 2; RBD, receptor-binding domain; ADCC, antibody-dependent cell-mediated cytotoxicity; ADCP, antibody-dependent cellular phagocytosis

SARS-CoV and SARS-CoV-2; thus, type II NAbs can generally neutralize both SARS-CoV and SARS$\mathrm{CoV}-2$ at the same time.

CR3022, a well-known monoclonal antibody $(\mathrm{mAb})$, was identified in a single-chain variable fragment phage display library constructed from lymphocytes of a recovered SARS patient ${ }^{[24]}$. It was initially thought that this antibody could not neutralize SARSCoV-2; however, a plaque-reduction neutralization test (PRNT) using SARS-CoV-2 virus and CR3022 showed a PRNT50 of 1:11 966. Nevertheless, the effectiveness of this antibody remains controversial. The neutralization mechanism of CR3022 may involve destabilization of the prefusion state after CR3022 is bound, thereby locking the RBD in the "up" state (fig. $2 \mathrm{~B})$. This premature postfusion state leads to further instability, thereby inactivating SARS-CoV- $2^{[25]}$. Likewise, EY6A uses a similar mechanism to lock the RBD in the "up" state, which causes the S protein to switch from the prefusion state to the postfusion state prematurely, resulting in instability ${ }^{[2]}$. VHH-72, which was isolated from llama immunized with the SARSCoV S protein and the MERS-CoV S protein, adopts a similar mechanism as that of CR3022 and EY6A; it locks the RBD in the "up" state (fig. 2B), destabilizing the $\mathrm{S}$ protein ${ }^{[27]}$. The binding position of $\mathrm{H} 014$ is relatively conserved in SARS-CoV and SARS-CoV-2, and the binding of $\mathrm{H} 014$ prevents the binding of the RBD to ACE2 due to steric hindrance ${ }^{[28]}$. In summary, type II NAbs can lock the RBD in the "up" state, which causes the $S$ protein to become unstable, and some type II NAbs can also interfere with the interaction of the RBD and ACE2 through steric hindrance.

\subsection{Type III NAbs}

In contrast to type I and type II NAbs, type III NAbs can bind only to the "down" state RBD (table 1, fig. 2C). For BD23, only the variable domain of the heavy chain is involved in the binding of the RBD, and the light chain is far away from the RBD region. Interestingly, N-linked glycans on N165 in the NTD of the adjacent $\mathrm{S}$ protomer promotes binding (fig. 2C).
When the RBD is in the "up" state, the BD23 binding site is far away from N165, which may affect the binding of the antibody. The binding epitope of BD23 overlaps with ACE2; therefore, it acts through steric hindrance and competition to prevent virus invasion ${ }^{[29]}$. S2M11 can prevent the binding of ACE2 to the RBD and lock the $\mathrm{S}$ protein in a closed conformation by recognizing two adjacent RBDs (fig. 2C). S2M11 has shown 2-5 orders of magnitude decrease in the amount of viral RNA detected in the lungs ${ }^{[30]}$. Fabs $2-4$ form additional interactions with $\mathrm{N}$-glycans on $\mathrm{N} 481$ and $\mathrm{N} 343^{[31]}$. The transformation of the "down" state of the RBD to the "up" state does not cause conformational disturbances; therefore, theoretically, the epitope bound by these antibodies is accessible whether the RBD is in the "up" state or the "down" state, but these antibodies can bind only when the RBD is in the "down" state and cannot bind an RBD in the "up" state. Analysis of the structure seems to suggest that because these NAbs only bind to one "down" RBD through their heavy chain and interact with glycosylation sites on an adjacent RBD or NTD to stabilize the binding; when the RBD is in the "up" state, the binding to the adjacent position is abolished. In other words, glycosylation sites play important roles in the binding of antibodies with the RBD. In summary, NAbs that bind to the "down" state RBD mainly lock the RBD in the "down" state to prevent the S protein from binding to ACE2, thereby preventing the virus from invading the host cell, and this process may require the participation of glycosylation sites.

\subsection{Type IV NAbs}

Type IV NAbs can bind to both the "up" state and the "down" state RBD (table 1, fig. 2D). Structural studies have revealed that two different regions are targeted by type IV NAbs: one is located on the $\mathrm{RBM}$, and the other is located on the side of the RBD with little or no overlap with the RBM. In the former case, P2B-2F6 binds to the RBM, similar to type III NAbs, and binds to the side of the RBD, similar to type I NAbs (fig. 2A, 2C, and 2D). The high binding 
affinity between P2B-2F6 and the RBD $(5.14 \mathrm{nM})$ is similar to the high-binding affinity between ACE2 and the RBD (4.70 nM); therefore, P2B-2F6 may not only prevent the RBD from binding to ACE2 through steric hindrance but also may compete with ACE2 to bind to the $\mathrm{RBD}^{[32]}$. For the latter case, $\mathrm{Sb} 23$ is a nanobody selected from a synthetic library that targets the RBD. Sb23 binds either the RBD in the "up" state or the "down" state without steric hindrance (fig. 2D). Interestingly, the bivalent $\mathrm{Sb} 23-\mathrm{Fc}$ constructs neutralize pseudovirus with an $\mathrm{IC}_{50}$ of $7 \mathrm{ng} / \mathrm{mL}$ and display about 100-fold improved neutralization potential; however, the underlying mechanism is unclear ${ }^{[33]}$. S309 was isolated from a patient who was infected with SARS$\mathrm{CoV}$ in 2003 and shows cross-reactivity between SARS-CoV and SARS-CoV-2 because 17 of the 22 residues are strictly conserved, and a glycan at position N343 (N330 in SARS-CoV) is highly conserved ${ }^{[34]}$. S309 recognizes a proteoglycan epitope on the RBD, but it is far away from the RBM and imposes no steric hindrance on ACE2.

\subsection{Type V NAbs}

Type V NAbs target non-RBD regions, including the NTD and S2 (table 1, fig. 2E). Because antibodies that bind to these two regions cannot directly block the binding of the RBD to ACE2, this type of antibody may induce ADCC or ADCP, prevent conformational changes required for membrane fusion, sterically interfere with ACE2 on virions, and function through other mechanisms. Since NAbs against the NTD and S2 have neutralizing activity and have completely different epitopes than antibodies against the RBD, type V NAbs may be used in combination with others in cocktails.

For example, 4A8 binds to the NTD region (fig. 2E). A previous study has shown that mAb 7D10 may bind to the NTD of the MERS-CoV S protein, possibly inhibiting the binding of RBD-DPP4 and the conformational changes of the $\mathrm{S}$ protein before and after fusion ${ }^{[9]}$. An analysis of the complex structure of the $4 \mathrm{~A} 8$ and $\mathrm{S}$ proteins reveals that $4 \mathrm{~A} 8$ is distant from the RBD and cannot block the interaction of the SARSCoV-2 RBD and ACE2. Therefore, the mechanism of action of 4A8 may be similar to that of 7D10, which neutralizes virus by restraining the conformational changes of the $S$ protein. Interestingly, the glycosylation site of N149 on the NTD is close to the 4A8-NTD interface ${ }^{[35]}$. In addition, the NTD of SARS-CoV-2 also has been shown to participate in the entry of host cells by targeting the tyrosine-protein kinase receptor $\mathrm{UFO}^{[36]}$. Therefore, NAbs that target the NTD may also block the binding of the NTD to the receptor, thereby affecting the viral invasion of host cells; however, to support this possible mechanism, more experimental evidence is needed.

There are numerous antibodies that bind the
SARS-CoV-2 S2 domain, for example, FC118, FC120, $\mathrm{FC122}$, and $\mathrm{FC} 124$. Interestingly, because of the high conservation of the S2 domain, these four NAbs exhibit cross-neutralization activity against SARS$\mathrm{CoV}-2$ and SARS-CoV ${ }^{[37]}$. These results indicate that the S2 domain may be a good choice for designing broad NAbs.

In summary, most of the NAbs that have been discovered are directed against the RBD region. Some of them block binding to ACE2 after binding to the RBD. There are also antibodies that lock the RBD in the "up" state, promoting the S protein to transit from a prefusion state to a postfusion state prematurely, leading to instability, or they lock the RBD in the "down" state to prevent it from binding to ACE2. Some antibodies induce ADCC or ADCP. In addition, studying NAbs against non-RBD regions will help us to understand how SARS-CoV-2 infects host cells, discover new cell surface receptors, and identify new drug targets. Moreover, NAbs against S2 or the NTD usually bind to conserved epitopes. These antibodies can effectively neutralize both SARS-CoV and SARS-CoV-2. These antibodies may serve as seeds for the development of broadly NAbs and broad-spectrum vaccines.

\subsection{Anti-SARS-CoV-2 NAbs Against SARS-CoV-2 Mutants}

SARS-CoV-2 is a single-stranded RNA virus, and it easily acquires mutations during the replication process. As of June 3, 2021, according to the World Health Organization (https://www.who.int/en/activities/ tracking-SARS-CoV-2-variants/), the B.1.1.7, B.1.351, P.1, and B.1.617.2 mutants are SARS-CoV-2 variants of concern. The production of mutant strains during the spread of the epidemic has an extremely negative impact on the control of the epidemic. The emergence of mutant strains may cause recovered patients to be reinfected, resulting in reduced or even ineffective NAbs and vaccines.

The D614G mutation may be related to increased infectivity ${ }^{[38]}$; however, studies have shown that plasma from recovered patients or plasma from vaccinated persons can neutralize this mutant ${ }^{[39]}$. The SARSCoV-2 variant B.1.1.7 (501Y. V1, also termed alpha) emerged in the United Kingdom and was associated with a surge of COVID-19 cases. It has nine mutations on the S protein, six in S1, and three in S2. N501 in the RBD area has been linked to increased human-human transmissibility ${ }^{[40]}$. Variants B.1.351 (501Y. V2, also termed beta $)^{[41]}$ and P.1 (501Y.V3, also termed gamma) $)^{[42]}$ also have been reported to increase infectivity and contain 9 and 11 mutations in the S protein, respectively, including 3 mutations in the RBD region: K417N/T, E484K, and N501Y. A cocktail of NAbs (REGNCOV2, consisting of REGN10987 and REGN10933) that target different regions and the NAbs LY-CoV555 and REGN10989 were tested against pseudoviruses 
harboring these mutations. The results showed that REGN10987 can effectively inhibit the invasion of host cells by viruses containing these three mutants, while the entry driven by the $\mathrm{S}$ protein of the B.1.351 and P.1 variants can partially resist REGN10933; therefore, an antibody cocktail (REGN-COV2) can effectively inhibit $\mathrm{S}$ protein-mediated invasion of all three variants. The entry mediated by the $S$ protein of the B.1.351 and P.1 variants can completely resist REGN10989 and LY-CoV555. All the tested antibodies effectively inhibited the B.1.1.7 variant. At the same time, tests on the plasma of some COVID-19 patients have shown that only partial protection is conferred against SARS-CoV-2 B.1.351 and P.1 mutant infections ${ }^{[43]}$. These results clearly show that antibody cocktail therapy against complementary epitopes is generally more effective than single-antibody cocktail therapy. Theoretically, by combining the different types of antibodies listed in table 1, it is reasonable to argue that more antibody cocktails can be designed to treat COVID-19.

The recent mutant strain B.1.617 has D111D, G142D, L452R, E484Q, D614G, and P681R mutations. Structural analysis has shown that mutations in the RBD, i.e., L452R, E484Q, and P681R at the furin cleavage site, may increase ACE2 binding and the rate of S1S2 cleavage, thus resulting in better transmissibility ${ }^{[44]}$. At the same time, it has been demonstrated that convalescent plasma samples from COVID-19 patients and individuals vaccinated with BBV152 (Covaxin) were able to neutralize B.1.617 $7^{[45]}$. Another similar variant of concern, B.1.617.2 (also termed delta), with mutations L452R, T478K, P681R, and T478K, may have the ability to escape an antibody ${ }^{[46]}$. However, whether these mutants can escape other vaccines and NAbs remains to be determined with further investigation.

\section{DISCUSSION}

The global pandemic of COVID-19 has seriously threatened people's lives and health as well as caused serious economic losses. In the absence of specific medicines, and because most countries and regions have not received enough vaccines to create an effective immune barrier, the NAb is one of the most promising choices for treating COVID-19. Some NAbs and antibody cocktails have been authorized for emergency use, and more antibodies are under development. As increasing numbers of NAbs-S (or RBD) structures are discovered, it will be easier to determine the precise binding epitopes on the $\mathrm{S}$ protein and facilitate our understanding of the detailed mechanisms of neutralizing activities. By knowing the binding epitopes and the mechanisms, cocktails of SARS-CoV-2 NAbs can be readily designed. Theoretically, they will be more effective and more resistant to the current and future mutants than single NAbs.

Knowledge of the binding epitopes of the NAbs may also provide hints for the design and development of vaccines. For traditional vaccine design, the success rate of candidate vaccines through clinical development from phase 1 to phase 3 is $16.2 \%$; furthermore, it has been predicted that the average development timetable for a candidate vaccine is 10.71 years, and the market entry rate is only $6 \%{ }^{[47,48]}$. Obviously, this is a low success rate and long-term process, which is not suitable for dealing with outbreaks. The emergence of mRNA vaccines has greatly accelerated the development of SARS-CoV-2 vaccines. Theoretically, peptide vaccines based on NAb epitopes have several advantages, such as fast production, easy storage, and convenient transportation.

The AbMap technology proposed by Qi et al ${ }^{[49]}$ enables high-throughput analysis of antibody-binding epitopes on antigens at amino acid-level resolution. AbMap has already been applied for dissecting SARS$\mathrm{CoV}-2$-specific epitopes ${ }^{[50]}$. Additional findings using this tool may facilitate our understanding of the SARS$\mathrm{CoV}-2$-specific immune response, at least in terms of humoral immunity. In addition, the epitopes may serve as precise antigens for new vaccine development, which is worthy of future investigation.

\section{Conflict of Interest Statement}

The authors declare no competing interests.

\section{REFERENCES}

1 Beigel JH, Tomashek KM, Dodd LE. Remdesivir for the Treatment of Covid-19-Preliminary Report. Reply. New Engl J Med, 2020,383(10):994

2 Group RC. Dexamethasone in hospitalized patients with Covid-19. New Engl J Med, 2021,384(8):693-704

3 Shen C, Wang Z, Zhao F, et al. Treatment of 5 Critically Ill Patients With COVID-19 With Convalescent Plasma. JAMA, 2020,323(16):1582-1589

4 Simonovich VA, Burgos Pratx LD, Scibona P, et al. A Randomized Trial of Convalescent Plasma in Covid-19 Severe Pneumonia. N Engl J Med, 2021,384(7):619629

5 Stanworth S. Convalescent plasma in the management of moderate covid-19 in adults in India: open label phase II multicentre randomized controlled trial. Transfus Med, 2020,371:m3939

6 Finkelstein MT, Mermelstein AG, Parker Miller E, et al. Structural Analysis of Neutralizing Epitopes of the SARS-CoV-2 Spike to Guide Therapy and Vaccine Design Strategies. Viruses, 2021,13(1):134

7 Huang Y, Sun H, Yu H, et al. Neutralizing antibodies against SARS-CoV-2: current understanding, challenge and perspective. Antib Ther, 2020,3(4):285-299

8 Corti D, Purcell LA, Snell G, et al. Tackling COVID-19 with neutralizing monoclonal antibodies. Cell, 2021,184(17):4593-4595

9 Zhou H, Chen Y, Zhang S, et al. Structural definition 
of a neutralization epitope on the N-terminal domain of MERS-CoV spike glycoprotein. Nat Commun, 2019,10(1):3068

10 Wrapp D, Wang N, Corbett KS, et al. Cryo-EM structure of the 2019-nCoV spike in the prefusion conformation. Science, 2020,367(6483):1260-1263

11 Cai Y, Zhang J, Xiao T, et al. Distinct conformational states of SARS-CoV-2 spike protein. Science, 2020,369(6511):1586-1592

12 Walls AC, Tortorici MA, Snijder J, et al. Tectonic conformational changes of a coronavirus spike glycoprotein promote membrane fusion. Proc Natl Acad Sci USA, 2017,114(42):11 157-11 162

13 Zang R, Gomez Castro MF, McCune BT, et al. TMPRSS2 and TMPRSS4 promote SARS-CoV-2 infection of human small intestinal enterocytes. Sci Immunol, 2020, 5(47):eabc3582

14 Walls AC, Park YJ, Tortorici MA, et al. Structure, Function, and Antigenicity of the SARS-CoV-2 Spike Glycoprotein. Cell, 2020,181(2):281-292, e6

15 Hoffmann M, Kleine-Weber H, Schroeder S, et al. SARS-CoV-2 Cell Entry Depends on ACE2 and TMPRSS2 and Is Blocked by a Clinically Proven Protease Inhibitor. Cell, 2020,181(2):271-280, e8

16 Glowacka I, Bertram S, Muller MA, et al. Evidence that TMPRSS2 activates the severe acute respiratory syndrome coronavirus spike protein for membrane fusion and reduces viral control by the humoral immune response. J Virol, 2011,85(9):4122-4134

17 Shulla A, Heald-Sargent T, Subramanya G, et al. A transmembrane serine protease is linked to the severe acute respiratory syndrome coronavirus receptor and activates virus entry. J Virol, 2011,85(2):873-882

18 Hsieh CL, Goldsmith JA, Schaub JM, et al. Structurebased design of prefusion-stabilized SARS-CoV-2 spikes. Science, 2020,369(6510):1501-1505

19 White JM, Delos SE, Brecher M, et al. Structures and mechanisms of viral membrane fusion proteins: multiple variations on a common theme. Crit Rev Biochem Mol Biol, 2008,43(3):189-219

20 Barnes CO, West AP, Huey-Tubman KE, et al. Structures of Human Antibodies Bound to SARS-CoV-2 Spike Reveal Common Epitopes and Recurrent Features of Antibodies. Cell, 2020,182(4):828-842, e16

21 Kreye J, Reincke SM, Kornau HC, et al. A Therapeutic Non-self-reactive SARS-CoV-2 Antibody Protects from Lung Pathology in a COVID-19 Hamster Model. Cell, 2020,183(4):1058-1069, e19

22 Shi R, Shan C, Duan X, et al. A human neutralizing antibody targets the receptor-binding site of SARSCoV-2. Nature, 2020,584(7819):120-124

23 Wu Y, Wang F, Shen C, et al. A noncompeting pair of human neutralizing antibodies block COVID-19 virus binding to its receptor ACE2. Science, 2020, 368(6496):1274-1278

24 Meulen JT, van den Brink EN, Poon LLM, et al. Human Monoclonal Antibody Combination against SARS Coronavirus: Synergy and Coverage of Escape Mutants. PLoS Med, 2006,3(7):e237

25 Huo J, Zhao Y, Ren J, et al. Neutralization of SARSCoV-2 by destruction of the prefusion Spike. Cell Host Microbe, 2020,28(3):445-454, e6
26 Zhou D, Duyvesteyn HME, Chen CP, et al. Structural basis for the neutralization of SARS-CoV-2 by an antibody from a convalescent patient. Nat Struct Mol Biol, 2020,27(10):950-958

27 Wrapp D, DeVlieger D, Corbett KS, et al. Structural Basis for Potent Neutralization of Betacoronaviruses by Single-Domain Camelid Antibodies. Cell, 2020,181(5):1004-1015, e15

28 Lv Z, Deng YQ, Ye Q, et al. Structural basis for neutralization of SARS-CoV-2 and SARS$\mathrm{CoV}$ by a potent therapeutic antibody. Science, 2020,369(6510):1505-1509

29 Cao Y, Su B, Guo X, et al. Potent Neutralizing Antibodies against SARS-CoV-2 Identified by HighThroughput Single-Cell Sequencing of Convalescent Patients' B Cells. Cell, 2020,182(1):73-84

30 Tortorici MA, M Beltramello, FA Lempp, et al. Ultrapotent human antibodies protect against SARSCoV-2 challenge via multiple mechanisms. Science, 2020,370(6519):950-957

31 Liu L, Wang P, Nair MS, et al. Potent neutralizing antibodies against multiple epitopes on SARS-CoV-2 spike. Nature, 2020,584(7821):450-456

$32 \mathrm{Ju} \mathrm{B}$, Zhang Q, Ge J, et al. Human neutralizing antibodies elicited by SARS-CoV-2 infection. Nature, 2020,584(7819):115-119

33 Custodio TF, Das H, Sheward DJ, et al. Selection, biophysical and structural analysis of synthetic nanobodies that effectively neutralize SARS-CoV-2. Nat Commun, 2020,11(1):5588

34 Pinto D, Park YJ, Beltramello M, et al. Structural and functional analysis of a potent sarbecovirus neutralizing antibody. bioRxiv, 2020,04.07.023903

35 Chi X, Yan R, Zhang J, et al. A neutralizing human antibody binds to the N-terminal domain of the Spike protein of SARS-CoV-2. Science, 2020,369(6504):650655

36 Wang S, Qiu ZY, Hou YN, et al. AXL is a candidate receptor for SARS-CoV-2 that promotes infection of pulmonary and bronchial epithelial cells. Cell Research, 2021,31(2):126-140

37 Zhang L, Cao L, Gao X, et al. A proof of concept for neutralizing antibody-guided vaccine design against SARS-CoV-2. bioRxiv, 2020.

38 Plante JA, Liu Y, Liu J, et al. Spike mutation D614G alters SARS-CoV-2 fitness. Nature, 2021,592(7852):116-121

39 Korber B, Fischer WM, Gnanakaran S, et al. Tracking Changes in SARS-CoV-2 Spike: Evidence that D614G Increases Infectivity of the COVID-19 Virus. Cell, 2020,182(4):812-827, e19

40 Kidd M, Richter A, Best A, et al. S-variant SARS-CoV-2 lineage B1. 1.7 is associated with significantly higher viral loads in samples tested by ThermoFisher TaqPath RT-qPCR. J Infect Dis, 2021,223(10):1666-1670

41 Mwenda M, Saasa N, Sinyange N, et al. Detection of B.1.351 SARS-CoV-2 Variant Strain-Zambia, December 2020. Morb Mortal Weekly Rep, 2021,70(8):280-282

42 da Silva Francisco Jr R, Benites LF, Lamarca AP, et al. Pervasive transmission of E484K and emergence of VUI-NP13L with evidence of SARS-CoV-2 coinfection events by two different lineages in Rio Grande do Sul, Brazil. Virus Res, 2021,296:198 345 
43 Hoffmann M, Arora P, Gross R, et al. SARS-CoV-2 variants B.1.351 and P.1 escape from neutralizing antibodies. Cell, 2021,184(9):2384-2393, e12

44 Cherian S, Potdar V, Jadhav S, et al. Convergent evolution of SARS-CoV-2 spike mutations, L452R, E484Q and P681R, in the second wave of COVID-19 in Maharashtra, India. bioRxiv, 2021.9(7):1542

45 Yadav PD, Sapkal GN, Abraham P, et al. Neutralization of variant under investigation B.1.617 with sera of BBV152 vaccinees. Clin Infect Dis, 2021:ciab411

46 Singh J, Rahman SA, Ehtesham NZ, et al. SARS-CoV-2 variants of concern are emerging in India. Nat Med, 2021,27(7):1131-1133

47 Pronker ES, Weenen TC, Commandeur H, et al. Risk in vaccine research and development quantified. PLoS One, 2013,8(3):e57755

48 Le TT, Cramer JP, Chen R, et al. Evolution of the COVID-19 vaccine development landscape. Nat Rev Drug Discov, 2020,19(10):667-668

49 Qi H, Ma M, Hu C, et al. Antibody binding epitope Mapping (AbMap) of hundred antibodies in a single run. Mol Cell Proteomics, 2021:100 059

50 Li Y, Lai DY, Zhang NH, et al. Linear epitopes of SARS-CoV-2 spike protein elicit neutralizing antibodies in COVID-19 patients. Cell Mol Immunol, 2020,17(10):1095-1097

51 Shi R, Shan C, Duan X, et al. A human neutralizing antibody targets the receptor-binding site of SARSCoV-2. Nature, 2020,584(7819):120-124

52 Hurlburt NK, Seydoux E, Wan YH, et al. Structural basis for potent neutralization of SARS-CoV-2 and role of antibody affinity maturation. Nat Commun, 2020,11(1):5413

53 Rogers TF, Zhao R, Huang D, et al. Isolation of potent
SARS-CoV-2 neutralizing antibodies and protection from disease in a small animal model. Science, 2020,369(6506):956-963

54 Du S, Cao Y, Zhu Q, et al. Structurally Resolved SARSCoV-2 Antibody Shows High Efficacy in Severely Infected Hamsters and Provides a Potent Cocktail Pairing Strategy. Cell, 2020,183(4):1013-1023, e13

55 Wu NC, Yuan M, Liu H, et al. An alternative binding mode of IGHV3-53 antibodies to the SARS-CoV-2 receptor binding domain. bioRxiv, 2020:2020.07.26.222232

56 Hansen J, Baum A, Pascal KE, et al. Studies in humanized mice and convalescent humans yield a SARS-CoV-2 antibody cocktail. Science, 2020,369(6506):1010-1014

57 Piccoli L, Park YJ, Tortorici MA, et al. Mapping Neutralizing and Immunodominant Sites on the SARS-CoV-2 Spike Receptor-Binding Domain by Structure-Guided High-Resolution Serology. Cell, 2020,183(4):1024-1042, e21

58 Huo J, Zhao Y, Ren J, et al. Neutralization of SARSCoV-2 by destruction of the prefusion spike. Cell Host Microbe, 2020,28(3):445-454, e6

59 Pinto D, Park YJ, Beltramello $\mathrm{M}$, et al. Crossneutralization of SARS-CoV-2 by a human monoclonal SARS-CoV antibody. Nature, 2020,583(7815):290-295

60 Huo J, Le Bas A, Ruza RR, et al. Neutralizing nanobodies bind SARS-CoV-2 spike RBD and block interaction with ACE2. Nat Struct Mol Biol, 2020,27(9):846-854

61 Hanke L, Vidakovics Perez L, Sheward DJ, et al. An alpaca nanobody neutralizes SARS-CoV-2 by blocking receptor interaction. Nat Commun, 2020,11(1):4420

62 Barnes CO, Jette CA, Abernathy MF, et al. SARS-CoV-2 neutralizing antibody structures inform therapeutic strategies. Nature, 2020,588(7839):682-687

(Received Jun. 8, 2021; accepted Jul. 26, 2021) 